\title{
Den grundtvigske inspiration til de nutidige afgørelser
}

\author{
Af Jens Rasmussen
}

Birthe Rønn Hornbech, Gud, Grundtvig, Grundlov. Statsmagt og åndsliv. Forlaget Gyldendal, København 2009, 159 sider.

Birthe Rønn Hornbechs bog er ikke en bog om Grundtvig, men der er tale om en debatbog, som henter sin inspiration i Grundtvigs tanker og søger at give et grundtvigsk svar på vor tids samfundsdiskussioner. Hun siger det direkte: "Jeg har læst Grundtvig ind i min situation og min tid og med mine forudsætninger” (13).

Det folkelige fallesskab: Denne bog adskiller sig ikke fra så meget andet grundtvigsk inspireret litteratur, hvor man kan risikere at gøre lidt vold på Grundtvigs mange udsagn sagt $\mathrm{i}$ hans egen tid $\mathrm{i}$ ganske bestemte situationer. Disse udsagn står altid i fare for at blive til generaliseringer, når de nu skal passe til nutidens situation, som er helt anderledes end for små 200 år siden. Alligevel er denne bog mere gennemført end de fleste i genren.

Et eksempel kan nævnes på denne fare for generalisering. Bogens omtale af fællesskabsbegrebet hos Grundtvig omtaler blot det folkelige statsborgerfællesskab som grundlaget, idet dette ifølge Grundtvig nøje skal adskilles fra det kristelige. Det betyder - ifølge forfatteren - i dagens Danmark, at vi inspireret af Grundtvig kan have multikulturelt fællesskab, selv om vi går til hver sin gudstjeneste. Fællesskabet har vi som borgere og ikke gennem religionen. Det kan være sandt nok. Men problemet med Grundtvig er, at han i Danskeren og andre steder taler om, at det folkelige fællesskab er man født ind i som danskere. Han er fra en tid, hvor det var nyopdaget, at fædrelandet og sproget (modersmålet) var det centrale. Folket var en stamme forskellig fra for eksempel jødernes stamme. Det var imod skabelsesordenen at gøre om på denne forskel! (jf. Vind 1999, 111-124, 269 ff., 461-474 og Korsgaard 2004, 212 ff., 216 ff., 281-88).

Grundtvig skelnede mellem statsborgerfællesskabet og det folkelige fædrelandsfællesskab. Birthe Rønn Hornbech taler kun om det første og glemmer det sidste, som aldrig for Grundtvig kan tolkes som et multikulturelt fællesskab. Medtager man kun Grundtvigs forståelse af statsborgerfællesskabet i sin inspiration til nutidens multikulturelle fællesskab, bliver der således tale om en generalisering. Noget andet er, at Grundtvig aldrig ville kunne have forestillet sig vores multikul- 
turelle fællesskab. På hans tid var der kun ca. 6000, som tilhørte andre trossamfund ud af en dansk befolkning på 1,4 mill. Altså over $99 \%$ tilhørte den lutherske enhedskultur. Skal Grundtvigs forståelse endelig omsættes til vor tid, er det mere nærliggende for forfatteren at stille krav til indvandrere om tilegnelse af dansk sprog og fædrelandskærlighed. Det ville Grundtvig nok ikke synes var for meget!

Magt og frihed: Birthe Rønn Hornbech nævner, at især Grundtvigs Rigsdagstaler fra 1848-49 har haft hendes interesse. Grundtvigs tanker om magt og frihed er væsentlige her. Hun spørger om, hvor meget staten skal blande sig i borgernes liv, og hvad der bør overlades til den enkelte. Gennemgangen og henvisningerne til Grundtvigs taler er ført med sikker hånd gennem hele bogen. Hun ser Grundtvigs taler ved Rigsforsamlingens grundlovsforhandlinger om for eksempel valgret, tokammersystem (som han var imod) og ytringsfrihed som en væsentlig inspirationskilde. Hendes konklusion er, at det netop er kristendommen, som fastholder statsmagten på, at der skal være et frirum for borgerne, og at der derigennem skabes den dynamik, som er nødvendig for at udvikle forskning og økonomi. Hun sætter ikke lighedstegn mellem kristendom og udvikling, men mellem frihed og udvikling. Frihed og liberalisme er således hendes Grundtviginspiration. Men hun har noget at have denne inspiration $\mathrm{i}$, når hun med Grundtvig mener, at forholdet mellem magt og frihed, mellem stat og borger, lader sig løse ud fra kristendommen med den lutherske skelnen mellem lov og evangelium, mellem det verdslige regimente og det åndelige regimente, for derved dæmmes der op for det totalitære. Således får Birthe Rønn Hornbech sine svar ved at læse Grundtvigs taler, og man kan kun give hende ret $i$, at det er meget vigtigt, at kristendommen bliver i det offentlige rum for at fastholde statsmagten på borgernes åndsfrihed. Det er så blevet et problem i dag, at kristendommen skal gemmes bort, men for Grundtvig for små 200 år siden var det derimod en selvfølge, at kristendommen var afgørende for fællesskabet og dets forudsætninger. Det vil Birthe Rønn Hornbech fastholde.

Religionsfriheden: Et andet hovedemne, som denne bog beskæftiger sig med, er Grundtvigs syn på religionsfriheden og friheden i kirken. Grundtvigs holdninger har bud til nutidens mange diskussioner om forholdet mellem religion og politik. Birthe Rønn Hornbech bruger flittigt Rigsdagens taler og finder det svar, at fællesskabet har vi ifølge Grundtvig ikke gennem religionen, men - som sagt - gennem det, at vi er fælles som borgere. Derfor skal religionsfriheden på grundtvigsk vis 
forstås i videst mulig omfang som tros- og samvittighedsfrihed for den enkelte.

Birthe Rønn Hornbech nævner dog ikke, at Grundtvig var så radikal, at han under grundlovsforhandlingerne i 1848-49 om religionsfriheden fandt, at paragraffen om denne "Gudsdyrkelsesfrihed" havde forrang for paragraffen om statens støtte til Folkekirkens fortrinsstilling. Hos de fleste grundlovsfædre var det med hensyn til kirke- og religionsparagrafferne sidstnævnte om Folkekirkens fortrinsstilling, som var hovedsagen. Frihedssynet var det afgørende for Grundtvig.

Grundlovsdebatten i 1849 viste, at flertallet havde den holdning, at statens anerkendelse af andre trossamfund kun kunne ske ud fra en vurdering af trossamfundets lære set i sammenhæng med sædelighed og offentlig orden. Grundtvig protesterede og mente, at det ville begrænse den frie gudsdyrkelse, og at der kun burde ske indskrænkninger af ordensmæssig karakter i religionsfriheden. På baggrund af Grundtvigs holdning mener Birthe Rønn Hornbech, at der ikke hidtil har været tale om indskrænkninger af religionsfriheden, men at der er en reel fare i fremtiden for, at det læremæssige og ordensmæssige sammenkædes. Dog må dertil bemærkes, at der har været indskrænkninger over for baptisterne, der i deres ansøgning til staten ikke kunne levere en skriftlig trosbekendelse til vurdering af, om læren stred imod den offentlige orden (jf. Matzen og Timm 1891). Baptisterne blev først anerkendt i 1952. Det må ikke glemmes!

Det drejer sig ifølge forfatteren om $\mathrm{i}$ administrationen af religionsfriheden at adskille lov og tro, om at give kejseren og Gud, hvad der tilkommer dem. Det har grundlovsskaberen D. G. Monrad tilfældigvis også sagt lidt anderledes: "Hele Religionsfriheden hviler paa, at man giver Kejseren, hvad Kejserens er, og Gud, hvad Guds er, at man giver Rigsdagen, hvad dens er, Kirkens Repræsentation, hvad dens er, Sogneforstanderskabet, hvad dets er, og Menigheden og Menighedsraadet, hvad deres er" (Nyholm 1947, 196). Tilføjelserne kunne Birthe Rønn Hornbech sikkert også have sagt!

Vores lutherske balance mellem stat og religion, mellem lov og tro får Birthe Rønn Hornbech til at være kritisk over for lovreligioner. Hun inddrager Grundtvigs åndsfrihed som det rette værn. Grundtvigs krav om tros- og åndsfrihed inden for lovens rammer og hans krav om den enkeltes ret til at fortolke Bibelen får således forfatterens gode ord med på vejen. For dette står i skærende kontrast til de lovreligioner, hvor lov og tro, stat og religion ikke kan adskilles. Så er det sagt! Derved anslår hun vor tids største fare, at åndsfriheden kværnes af den religiøse stat. 
Stat-kirke-forholdet: Der er en klar og konsekvent linje i denne bog, hvilket gør den til en god repræsentant for den genre, som kunne kaldes Grundtvig-inspirerede samfundsdebatbøger. Langt hen ad vejen er Birthe Rønn Hornbechs læsning af Grundtvig - og de biografier, hun oplyser at have læst (uden at sige hvilke) - en garant for korrektheden af de historiske indslag om Grundtvig. Her er der tale om en solid tradition, hvor hun starter med en skildring af den unge Grundtvigs kamp mod autoriteterne, ligesom hun skildrer Kirkens Gienmoele (Grundtvig 1825) og H. N. Clausens anlagte injuriesag i 1826.

Når det drejer sig om forståelsen af Grundtvigs forhold til religionsfriheden og stat-kirke-forholdet, mangler beskrivelsen af Grundtvigs forslag i 1834 i skriftet Den danske Stats-Kirke upartisk betragtet, der er ret vigtig (jf. Rasmussen 2009).

Kort sagt siger Birthe Rønn Hornbech om udviklingen i Grundtvigs syn på religionsfriheden, at han i slutningen af 1820'erne gik ind for en udskillelse fra Statskirken (og ikke en adskillelse mellem stat og kirke, som det senere misforståeligt siges s. 155). Grundtvig gik ind for den engelske model, hvor religionsfriheden betød, at der ved siden af statskirken skulle være plads til at danne frikirker. Således ønskede han det for de gammeldagstroende, der ikke kunne leve sammen med rationalisterne i Statskirken. Allerede i begyndelsen af 1830 'erne ændrede han kurs, for fædrene-troen havde han fælles med utallige, om han så end ikke havde dogmatik og eksegese fælles med en eneste! Han besluttede at blive i Statskirken og kæmpe for at få friheden inden for Statskirken. Grundtvig indtog det standpunkt med sit forslag i 1834, at Den evangelisk-lutherske Statskirke skulle være en konfessionsløs borgerlig (økonomiskjuridisk) indretning eller ramme om frie menigheder, hvor præst og menighed selv kunne vælge hinanden og mødes ud fra bekendelse og tro. Derved var lov og tro virkelig holdt adskilt. Han medtog også andre trossamfund, der frit under denne statskirkelige ramme kunne danne egne menigheder. Det gjaldt reformerte, katolikker, jøder og kvækere - og i 1840'erne ligeledes baptisterne. Så vidt var religionsfriheden tænkt med, ja var egentlig udgangspunktet for hele forståelsen. Forudsætningen for Grundtvigs forslag var sognebåndsløsning og præstefrihed i lære og liturgi.

Dette forslag har Grundtvig i tankerne på Rigsdagen i 1849. Derfor vil han ikke have "evangelisk-luthersk" med i Grandlovens paragraf om statens støtte til den evangelisk-lutherske Folkekirke. Folkekirken skulle være konfessionsløs og flertalskirke. Bogen medtager ikke rigtigt Grundtvigs forslag fra 1834 og konsekvenserne for en ad- 
skillelse af lov og tro. Derved bliver Grundtvigs holdning under grundlovsforhandlingerne i Rigsforsamlingen i 1849 mere uforståelig.

Rigtigt er det, som Birthe Rønn Hornbech siger det, at Grundtvig på sine gamle dage gik ind for, at Folketinget blev det organ, som gav kirkelove for Folkekirken, men så må det også oplyses i bogen, at det var det mulige - ja, den eneste måde, hvorpå han og hans venner kunne få etableret de kirkelige frihedslove med sognebåndsløsning (1855), valgmenigheder (1868) og ret til at bruge kirker (1872). Friheden i Folkekirken var hovedsagen - ja, målet helliger midlet!

Bogen anvender tilsyneladende ikke Grundtvigs holdning i grundlovsdebatten om sognebåndsløsning, hvor kravet var formuleret som paragraf af grundlovskomiteens mindretal, men paragraffen gled ud ved afstemningen.

Den grundtvigske interesse for Folketingets lovgivningsmagt skyldtes også tidens kirkeforfatningsdrøftelser. Grundtvigianerne opfattede ligefrem Folketinget som en "lægmandssynode" i forsøget på at undgå en kirkeforfatning, som Grundloven krævede, og som de grundtvigske frygtede ville blive gejstlighedens synode. Det var den gamle sag om den præstedominerede skriftkirke, som Grundtvig allerede gjorde op med i 1820 'erne - ja, siden 1810 med sin dimisprædiken. Det gjaldt kampen mod autoriteterne, som Birthe Rønn Hornbech formulerer det.

Prcestefrihed: Det lykkedes ikke for Grundtvig at få indført en præstefrihed, endsige at komme igennem med det forslag til en konfessionsløs folkekirkelig ordning, han fremkom med i 1834, og det gjorde ham temmelig frikirkelig på hans gamle dage. Dette afspejlede sig siden i Askov-adresserne fra 1880'erne og kravet om den "taalsomme" Folkekirke. Dette perspektiv havde også været rart at få med. Men ganske behændigt får Birthe Rønn Hornbech argumenteret for, at selvom vi i dag ikke har præstefriheden i liturgi og lære, viser den administrative praksis, at man ligger tæt på. Den eneste anstødssten, hun selv nævner, er loven om læresager, som Grundtvig nok ikke ville have accepteret. Men så trøstes vi med, at regeringens administrative håndtering af Grosbøll-sagen viste et stort frirum for præster. Forfatteren gør med et "amen" Grundtvigs ord til sine, når han siger, at den fulde glæde over Folkekirken forudsætter en tungebåndsløsning for præsterne (158). Hvor er den konfessionelle kirke henne? Og hvor bliver dog Birthe Rønn Hornbechs Grundtvigtidehvervske udgangspunkt af? Hun står i hvert fald ikke stille!

Et stort frirum for præster var også til debat blandt Grundtvigs egne præstevenner (Birkedal, Fenger m.fl.). Flere af disse kunne ikke gå ind for liturgisk og dogmatisk præstefrihed, hvilket Grundtvig var 
skuffet over. Grundtvig var efter 1849 mere og mere præget af et frikirkesyn, som samtiden betragtede som eksklusivt, det vil sige at han var dogmatisk og liturgisk fri for dem, som mente noget andet. Kierkegaard sagde netop, at Grundtvig kun ønsker frihed, så han og tilhængerne kan udtrykke, hvad de tror at forstå ved kristendom - og således kan han "beroliget i dette Liv (...) maaskee kalde sin Rolighed Tolerance mod de Andre, de andre - Christne" (Kierkegaard 1855, 261).

Alt i alt må bogen ses som vellykket, hvor forfatteren sætter sig grundigt ind i de historiske data, og hun viser også stor fortrolighed med Grundtvig-talerne. Det er vigtigt, at beslutningstagere vil bruge den historiske (og grundtvigske) inspiration til de nutidige afgørelser. Alt for meget ser vi politikere, som er vor tids signalgivere, svømme rundt $\mathrm{i}$ et historieløst rum. Derved svækkes samfundsfællesskabet, fordi vi ikke forstår hinanden, idet vi ikke er bevidste nok om vores fælles forudsætninger. Derfor er det en vigtig debatbog, der er værd at læse.

\section{Litteraturliste}

Grundtvig, N. F. S. (1825), Kirkens Gienmale imod Professor Theologice Dr. H. N. Clausen, København.

Kierkegaard, Søren (1855), "Øieblikket” nr. 6 i Samlede Skrifter, udg. af Søren Kierkegaard Forskningscenteret (2009), bind 13, København.

Korsgaard, Ove (2004), Kampen om folket. Et dannelsesperspektiv på dansk historie gennem 500 år, København.

Matzen, H. og Timm, Johs. (1891), Haandbog $i$ den danske Kirkeret, København.

Nyholm, Asger (1947), Religion og Politik: En Monrad Studie, København.

Rasmussen, Jens (2009), Religionstolerance og religionsfrihed. Forudsætninger og Grundloven i 1849, Odense.

Vind, Ole (1999), Grundtvigs historiefilosofi, København. 